
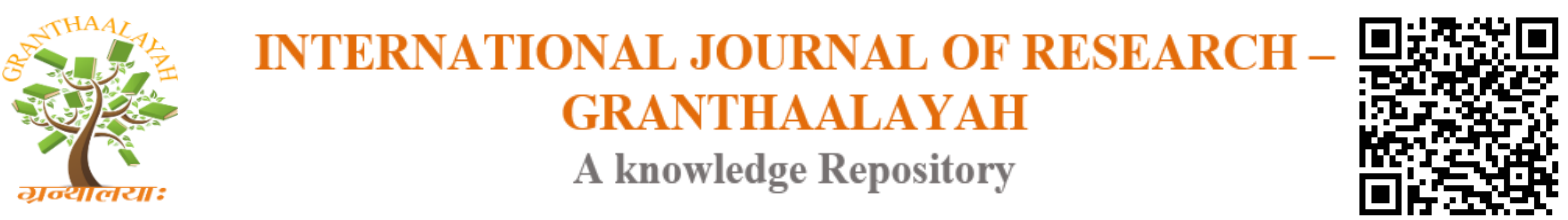

Science

\title{
THE RISK ASSESMENT AND IMPACT OF HYGIENIC CONDITIONS ON THE DEVELOPMENT OF LEGIONELLA SPP. IN WATER SYSTEMS OF PUBLIC AND TOURIST FACILITIES
}

\author{
Adna Bešić ${ }^{1}$, Zarema Obradović ${ }^{2,3}$, Adisa Dautbegović ${ }^{4}$, Amina Obradović ${ }^{2}$ \\ ${ }^{1}$ Public Health Institute FB\&H, Sarajevo, Bosnia \& Herzegovina \\ ${ }^{2}$ Public Health Institute of Sarajevo Canton, Sarajevo, Bosnia \& Herzegovina \\ ${ }^{3}$ Faculty of Health Studies, University of Sarajevo, Bosnia \& Herzegovina \\ ${ }^{4}$ Euroinspekt d.o.o.Sarajevo, p.j."'Real Inspekt", Sarajevo, Bosnia \& Herzegovina
}

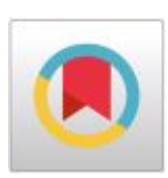

\begin{abstract}
A large number of different diseases are associated with the consumption of hygienic defective water and the use of water for maintaining personal hygiene. Recreational waters, water in systems intended for cooling and heating of public buildings are also significant. Among these diseases, the most significant is legionellosis, the disease which has become more and more important in the whole world in recent years. The aim of this paper was to evaluate the connection of hygienic conditions in public buildings with the appearance of genus Legionella in drinking and bathing water, as well as water from outside and inside fountains, pools and water from cooling and heating systems for public buildings. Obtained results are also used to evaluate the risk of developing legionellosis in the population of Bosnia and Herzegovina and among foreign tourists. The presence of Legionella spp. was analysed in 238 samples of water taken from faucets in rooms of buildings intended for people's accommodation, in open and closed fountains, pools, cooling and water systems. Hygienic conditions in the facilities were assessed using survey questionnaire and complemented with legionella findings. This study showed the direct correlation between hygienic conditions in public and tourist facilities with the presence of Legionella spp. in the waters taken in these objects.
\end{abstract}

Keywords: Leginella; Water; Hygienic Conditions; Public and Tourist Facilities.

Cite This Article: Adna Bešić, Zarema Obradović, Adisa Dautbegović, and Amina Obradović. (2017). "THE RISK ASSESMENT AND IMPACT OF HYGIENIC CONDITIONS ON THE DEVELOPMENT OF LEGIONELLA SPP. IN WATER SYSTEMS OF PUBLIC AND TOURIST FACILITIES." International Journal of Research - Granthaalayah, 5(11), 1-13. https://doi.org/10.29121/granthaalayah.v5.i11.2017.2319.

\section{Introduction}

Clean and safe water is one of the preconditions for a normal life and the basis of prevention for a large number of infectious diseases. Although in the industrialized world it is believed in the 
quality of water in water systems, the fact is that microbial water safety cannot be taken for guarantee (1).

One the causers that can be found in water and which are often neglected are legionelle. Legionella spp. is pathogenic bacteria that live in water. Legionella bacteria normally inhabit watercourses or wetlands, but the main sources of bacteria of this genus are objects made by humans, such as hot water plants, showers, cooling towers, spa centres, fountains, humidifiers and evaporative capacitors $(2,3)$. In running waters, legionella survive as intercellular parasites of free-living protozoa as their natural hosts $(4,5,6)$. In water supply systems, legionella are part of a biofilm that provides protection and nutrients, supports their survival and reproduction outside the host cell $(7,8$, and 9$)$.

Legionella are very demanding for cultivation. They do not grow on the usual nutrients, but only on special nutrient enriched with hemoglobin and with the addition of iron and amino acid L cysteine $(10,11)$.

L. pneumophila is a species of the genus Legionella most commonly associated with human diseases, especially inflammation of the lungs. It has been established that L. pneumophila is the most common cause of Legionary disease (12). People are infected with inhalation of aerosol created by the use of faucets and showers_(13). The association of chemical factors in water supply systems with the growth of legionella shows that low concentration of some metals such as iron, zinc and potassium, increases their reproduction. Therefore, the metal components and products of plumbing system corrosion (galvanized iron) can play a role in creating a biofilms that promotes the growth of bacteria of the genus Legionella (14).

Hot water contamination with legionella is associated with centralized water systems, a greater distance from heat sources and older water infrastructure, while copper in water has a protective effect $(15,16)$.

Many factors influence the accumulation of bacteria on the surface of the pipeline and the formation of biofilms, such as inadequate flow velocity or water stagnation, materials on the surface and roughness, concentration and quality of nutrients and disinfectants, temperature and system hydraulics (17). Biofilm is formed by a large number of bacteria including Legionella spp., Klebsiella spp., Pseudomonas spp., Mycobacterium, E. coli and other organisms such as protozoa (amoebae), parasites and enteroviruses (18, 19, 20). Microorganisms in biofilm are often resistant to biocides and are difficult to remove, especially from hard-to-reach areas such as the edges of the tube, T-joints and rough inner surfaces. Because of this, the number of $L$. pneumophila is 10 times higher on the tap itself than in the water inside the supply system (21). There are complex and symbiotic relations between legionella and other bacteria and protozoa (22). These relationships allow legionella essential living conditions such as intracellular replication and sequestration in amebae. The environmental biofilm provides legionella protection against harmful substances such as disinfectants and allows for a more convenient access to the eukaryotic host that is considered necessary for their replication in the environment (23). In addition, microorganisms on the surface are continuously released from biofilm into water that flows or stands in the lumen of the tube, and thus the biofilm becomes the primary reservoir for continuous contamination of the system $(24,25,26)$. 
The existence of a biofilm, or the presence of legionella, is a major problem in water pipes in tourist and public buildings because it poses a risk for the occurrence of disease. Tourism is the basic branch of the economy in many European countries and is sensitive to health threats. In order to protect the health of tourists, the European scheme for the control of cases of legionary travel related diseases was established in 1987 (27).

The aim of this paper was to determine the correlation of hygienic conditions in the facilities and positive water samples for the presence of Legonella spp. in public and tourist facilities on the territory of Bosnia and Herzegovina and to evaluate the epidemiological risk for the appearance of legionellosis.

\section{Materials and Methods}

A total of 238 samples were collected from tap water in the premises of catering facilities intended for accommodation, exterior and interior fountains, swimming pools and water contained in cooling and heating systems. The samples were taken across Bosnia and Herzegovina, during four seasons, in the period of 3 years. In the premises, the samples of hot water were collected from the water heating system (boilers), while the cold water samples were taken from the water supply system in the facilities. The water in cooling and heating systems was collected from the outlet tap from tanks. Hot water samples were collected from bathroom outlets (showerheads or bathroom taps), after water had flowed for 3-5 minutes to achieve continuous temperature. The water from cooling and heating systems intended for heating or cooling of the selected objects, was collected from the outlet tap from tanks. The samples were stored in $1000 \mathrm{ml}$ sterile glass bottles and immediately transported to the laboratory for microbiological analyses, using portable coolers (at $4^{\circ} \mathrm{C}$ ). Concentrations of free residual chlorine and water temperature were measured during sampling. The temperature was measured by immersing the probe with a calibrated thermometer, until the stabilization of temperature values on the display was reached. The free residual chlorine was measured by the standard colorimetric technique - the N, N-diethyl-phenylenediamine method (HANNA Instruments 96701, Rhode Island, USA). In order to neutralize free residual chlorine, sodium thiosulfate was added to the sterile bottles for bacteriological analysis $(20 \mathrm{mg} / \mathrm{l}$ according to BAS EN ISO 19458:2008). While collecting the samples, close intention was paid to distribution of premises in relation to the "dead" pipes and possible water retention in these pipes and pipe joints. Water supply data and sample volume, water temperature, as well as the presence and nature of the biocidal agent were recorded in the Work Order form. The form was submitted to laboratory along with the sample to be available to the staff that conducted the analysis and interpreted the results. All steps to ensure quality assurance of the laboratory performance for microbiological analysis were applied and recorded.

The analysis of Legionella in water samples was carried out using the method BAS EN ISO 11731-2:2009 - Water quality - Detection and enumeration of Legionella - Part 2: Direct membrane filtration method for waters with low bacterial counts. The detection limit of the procedure was $25 \mathrm{cfu} \times \mathrm{L}-1$ (the mean of 2 plates).

All facilities in the tested sample are classified in grades ranging from one to five, from poor to excellent, and according to hygienic conditions: 
- Grade 1: facilities with an infrastructure older than 20 years, visible layers of biofilm as a result of inadequate hygienic conditions were present, water disinfection was not carried out, the measurement of the residual chlorine concentration was not performed and there were no records of the value of hot and cold water temperature.

- Grade 2: facilities with an infrastructure older than 20 years, poor hygienic conditions of the environment observed, but without visible biofilm layers, water disinfection was carried out rarely and without defined dynamics, as well as measurement of the residual chlorine concentration and there was no record of temperature of hot and cold water.

- Grade 3: facilities with an infrastructure between 10 and 20 years, the average hygienic conditions of the environment but without the presence of biofilm, with defined dynamics of water system disinfection, periodically, and / or measurement of the residual chlorine concentration and the measurement of warm and cold water temperature, but without recorded data of it.

- Grade 4: facilities with infrastructure of less than 10 years, good hygienic conditions of the environment, free of biofilm layers, with defined dynamics of water system disinfection and / or measurement of the residual chlorine concentration and hot and cold water temperature, but without recorded data of it.

- Grade 5: facilities with infrastructure of less than 10 years whose construction took into account factors that could affect water stagnation and development of biofilms, excellent hygienic conditions in the environment, water disinfection was performed on a daily basis, as well as measurements of the residual chlorine concentration, hot and cold water temperature, with recorded data of it.

The assessment of hygienic conditions was determined based on the answers to the questionnaire. The survey was conducted for each of the examined objects. There were 18 questions in questionnaire related to all parameters that could have an impact on the appearance of bacteria from the genus Legionella in the water. Based on the answers to the questionnaire, a risk assessment was made.As results of the questionnaire the examined facilities were grouped in the category "unsatisfactory", rated with hygienic conditions 1, 2 and 3, and "satisfactory", rated with grades 4 and 5 .

The data obtained following the analysis of samples for the presence of Legionella, were statistically analysed by appropriate and verified methods, using a computer program Microsoft Excel 2010 and BioStat Pro version 5.8.3® software. It was also tested whether there is a statistically significant difference in the frequencies of positive and negative samples between faculties with different grades of hygienic conditions.

The results of the survey questions on the condition of the facilities and the manner of maintaining and controlling the hygienic conditions in them are expressed in percentages. In order to better understand the potential factors that influence the appearance of legionella in water, for each answer, the percentage representation of positive and negative results obtained by examining the presence of legionella in water samples from surveyed facilities is shown. 


\section{Results and Discussions}

238 samples of water taken from the tap in rooms of catering facilities intended for accommodation of people, in internal and external fountains, pools, water cooling and heating systems were analysed.

According to the results of the t-test shown in Table 1., there was no statistically significant difference in presence of legionella in drinking water and bathing water categories, nor in water samples from fountains, pools and cooling and heating system.

Table 1: Statistical indicators of hygienic conditions in facilities where a water samples were taken

\begin{tabular}{|c|c|c|c|c|}
\hline $\begin{array}{l}\text { Statistical } \\
\text { parameters }\end{array}$ & \multicolumn{2}{|c|}{$\begin{array}{l}\text { The presence of legionella in the water } \\
\text { samples from the rooms }\end{array}$} & \multicolumn{2}{|c|}{$\begin{array}{c}\text { The presence of legionella in water } \\
\text { samples from fountains, swimming } \\
\text { pools and cooling and heating } \\
\text { systems }\end{array}$} \\
\hline & $\begin{array}{l}\text { Legionella spp. } \\
\text { not isolated }\end{array}$ & $\begin{array}{l}\text { Legionella } \\
\text { spp. } \\
\text { isolated }\end{array}$ & $\begin{array}{l}\text { Legionella } \\
\text { spp. not } \\
\text { isolated }\end{array}$ & $\begin{array}{l}\text { Legionella } \\
\text { spp. } \\
\text { isolated }\end{array}$ \\
\hline Xav & 3,30 & 3,42 & 2,94 & 2,33 \\
\hline $\mathrm{S}$ & 0,80 & 0,71 & 0,80 & 1,25 \\
\hline sXav & 0,06 & 0,12 & 0,14 & 0,72 \\
\hline $\mathrm{V}$ & $24 \%$ & $21 \%$ & $27 \%$ & $53 \%$ \\
\hline $\mathrm{t}$ test & \multicolumn{2}{|c|}{0,88} & \multicolumn{2}{|c|}{1,13} \\
\hline p-value & \multicolumn{2}{|c|}{0,37} & \multicolumn{2}{|c|}{0,26} \\
\hline
\end{tabular}

AM - mean, SD - standard deviation; SEM - standard error of the mean; CV - variation coefficient; *statistically significant difference $\mathrm{p}<0,05$

Table 2: Comparative overview of the results of the $X^{2}$ test and the difference in the number of positive and negative results between groups of samples with different grades of hygienic conditions in rooms

\begin{tabular}{|c|c|c|c|c|}
\hline \multicolumn{5}{|c|}{ The presence of legionella } \\
\hline $\begin{array}{l}\text { The assessment } \\
\text { of hygienic } \\
\text { conditions of wet } \\
\text { nodes in the } \\
\text { rooms }\end{array}$ & $\begin{array}{c}\text { The number of } \\
\text { positive samples }\end{array}$ & $\begin{array}{l}\text { The number of } \\
\text { negative samples }\end{array}$ & $\begin{array}{c}\text { Total number Of } \\
\text { samples }\end{array}$ & $\begin{array}{l}\text { The percentage } \\
\text { of positive } \\
\text { samples } \\
(\%)\end{array}$ \\
\hline 1 & 0 & 0 & 0 & 0,00 \\
\hline 2 & 5 & 27 & 32 & 15,62 \\
\hline 3 & 12 & 71 & 83 & 14,45 \\
\hline 4 & 21 & 58 & 79 & 26,58 \\
\hline 5 & 0 & 166 & 10 & 0,00 \\
\hline Total & 38 & 166 & 204 & 18,63 \\
\hline $\mathrm{X}^{2}$ & & 29,46 & & \\
\hline p-value & & $0,00001 *$ & & \\
\hline
\end{tabular}


Table 3: Comparative overview of the results of the $X^{2}$ test and the difference in the number of positive and negative results between groups of samples with different grades of hygienic conditions in fountains, swimming pools, cooling and heating systems.

\begin{tabular}{|c|c|c|c|c|}
\hline $\begin{array}{l}\text { The assessment } \\
\text { of hygienic } \\
\text { conditions of } \\
\text { fountains, } \\
\text { swimming pools } \\
\text { and cooling and } \\
\text { heating systems }\end{array}$ & $\begin{array}{c}\text { Total number of } \\
\text { samples }\end{array}$ & $\begin{array}{c}\text { Percentage of } \\
\text { positive } \\
\text { samples }(\%)\end{array}$ & $\begin{array}{c}\text { Number of positive } \\
\text { samples }\end{array}$ & $\begin{array}{c}\text { Number of } \\
\text { negative samples }\end{array}$ \\
\hline 1 & 1 & 100 & 0 & 1 \\
\hline 2 & 11 & 9,09 & 10 & 1 \\
\hline 3 & 14 & 0 & 14 & 0 \\
\hline 4 & 7 & 14,28 & 6 & 1 \\
\hline 5 & 1 & 0 & 1 & 0 \\
\hline Total & 34 & 8,82 & 31 & 3 \\
\hline$X^{2}$ & \multirow{2}{*}{\multicolumn{4}{|c|}{$\begin{array}{c}12,04 \\
0,017 *\end{array}$}} \\
\hline $\mathrm{p}$-value & & & & \\
\hline
\end{tabular}

Out of the 34 water samples from the fountain, swimming pools, cooling and heating systems presented in Table 3., in facilities with grade 3,14 samples of water were collected and none of them were positive. Seven samples were from facilities with grade 4, and 1 of them (14.28\%) was positive.

The $\mathrm{X}^{2}$ test indicates that there is a statistically significant difference in the number of positive and negative results (the presence of legionella) among the facilities with differently graded hygienic conditions in waters intended for drinking and bathing, as well as in waters from fountains, swimming pools, cooling and heating systems. There are mostly positive test results recorded in facilities with better hygienic conditions.

The one of the criteria in assessing the risk of the presence of legionella is the age of facilities. The examined facilities were classified into one of the three groups. The highest percentage of facilities $(45.77 \%$ ) included in the survey was older than 20 years, $39.11 \%$ of the facilities were between 10 and 20 years old, while $15.04 \%$ of the facilities were under the age of 10 (Fig.1).

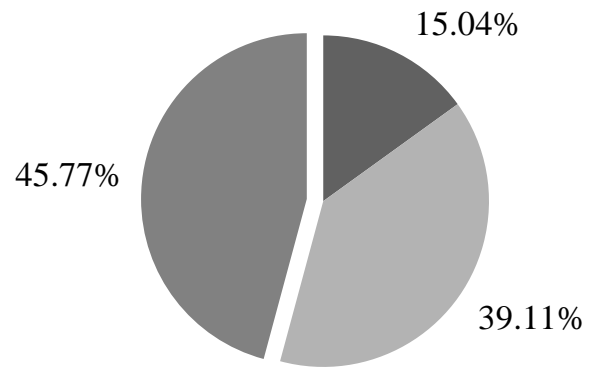

Less than 10 years

10-20 years

More than 20 years

Figure 1: The age structure of facilities in the sample 
According, to the mode of water supply, the facilities were classified into four categories as shown in Fig. 2. The largest number of facilities were supplied with water from the city water supply $(57.37 \%) .15,90 \%$ of the facilities were supplied from the local water supply system, and $7,32 \%$ of the exanimated facilities were supplied with individual water supply, wells and springs. $19.39 \%$ of the facilities had combined mode of water supply from the city water supply and local water supply.

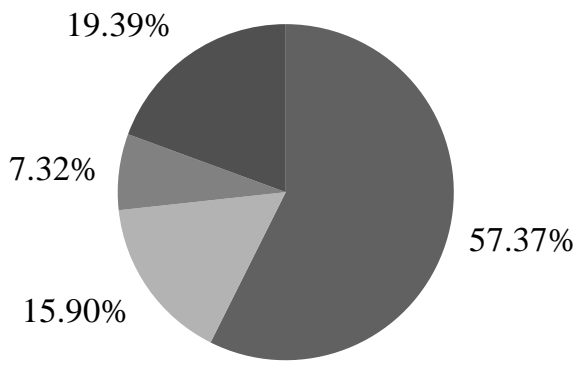

$$
\begin{aligned}
& \text { Central water supply } \\
& \text { Local water supply } \\
& \text { Individual water supply } \\
& \text { Central and local water } \\
& \text { supply }
\end{aligned}
$$

Figure 2: The overview of the water supply systems

Disinfection of the hot and cold water system was not performed in $84.31 \%$ of the examined facilities (Fig. 3), while $15.68 \%$ of the facilities disinfected the water supply system in some way.

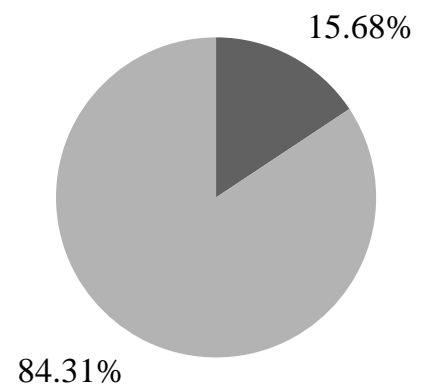

YES

$\square \mathrm{NO}$

Figure 3: The percentage review of the survey results for disinfection of hot and cold water systems

The control of the value of temperature and residual free chlorine in the water supply system was not performed in $60.34 \%$ of the exanimated facilities (Fig. 4).

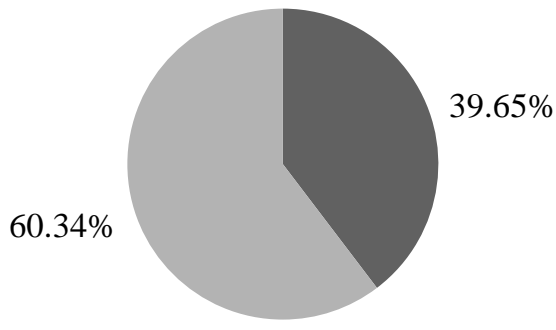

- YES

NO

Figure 4: The review of the implementation of temperature control and residual chlorine concentration 
Within the carried out survey, the facilities were categorized into one of three groups by age. The results of the question in the survey about the age of facilities in relation to the number of | positive samples are shown in Table 4.

Table 4: Connection between age of facilities and the presence of legionella in water

\begin{tabular}{|lccccc|}
\hline $\begin{array}{c}\text { The risk } \\
\text { factor }\end{array}$ & The age & $\begin{array}{c}\text { The number of } \\
\text { facilities with } \\
\text { negative } \\
\text { samples }\end{array}$ & $\begin{array}{c}\text { The number } \\
\text { of facilities } \\
\text { with positive } \\
\text { samples }\end{array}$ & Total & $\begin{array}{c}\text { The } \\
\text { percentage of } \\
\text { facilities with } \\
\text { positive } \\
\text { samples }\end{array}$ \\
\hline $\begin{array}{l}\text { The age of the } \\
\text { facilities }\end{array}$ & $10-20$ & 1 & 33 & 34 & $3 \%$ \\
& $>20$ & 10 & 93 & 88 & $33 \%$ \\
\hline
\end{tabular}

The highest number of samples positive for the presence of legionella was in the group of facilities aged between 10 and 20. There were 4 different ways of water supply. The most positive samples were detected $(24 \%)$ in the group of facilities where the supplying was combined, both public and local water supply, with 4 positive of 17 analysed samples from this group, as shown in Table 5.

Table 5: Connection between methods of water supply system in facilities and the presence of legionella in water

\begin{tabular}{|cccccc|}
\hline $\begin{array}{c}\text { The risk } \\
\text { factor }\end{array}$ & $\begin{array}{c}\text { Type of water } \\
\text { supply }\end{array}$ & $\begin{array}{c}\text { The number of } \\
\text { negative } \\
\text { samples }\end{array}$ & $\begin{array}{c}\text { The number } \\
\text { of positive } \\
\text { samples }\end{array}$ & Total & $\begin{array}{c}\text { The } \\
\text { percentage of } \\
\text { positive } \\
\text { samples }\end{array}$ \\
\hline Method of & Central & 12 & 121 & 133 & $9 \%$ \\
water & Local & 7 & 30 & 37 & $19 \%$ \\
supply & Central and local & 4 & 37 & 45 & $18 \%$ \\
& Total & 31 & 13 & 17 & $24 \%$ \\
& & 4 & 201 & 232 & $17,5 \%$ \\
\hline
\end{tabular}

The connection between the methods of disinfection of the water system and the presence of legionela in water were analysed. Forty facilities of the survey were placed in a group that disinfected the water system in one of the available ways, which makes $15.68 \%$ of the total sample. The remaining facilities did not apply any of the methods of disinfection of the water system $(84.31 \%)$, as shown in Fig. 5.

Table 6: The review of the results of the water samples analysis and answers to questionnaires

\begin{tabular}{|cccccc|}
\hline $\begin{array}{c}\text { Characteristic } \\
\text { of facilities }\end{array}$ & Answers & $\begin{array}{c}\text { Number of } \\
\text { negative } \\
\text { samples }\end{array}$ & $\begin{array}{c}\text { Number of } \\
\text { positive } \\
\text { samples }\end{array}$ & Total & $\begin{array}{c}\text { Percentage of } \\
\text { positive } \\
\text { samples }\end{array}$ \\
\hline $\begin{array}{c}\text { Disinfection } \\
\text { of cold and } \\
\text { hot water } \\
\text { systems }\end{array}$ & YES & 36 & 4 & 32 & $10 \%$ \\
\hline
\end{tabular}




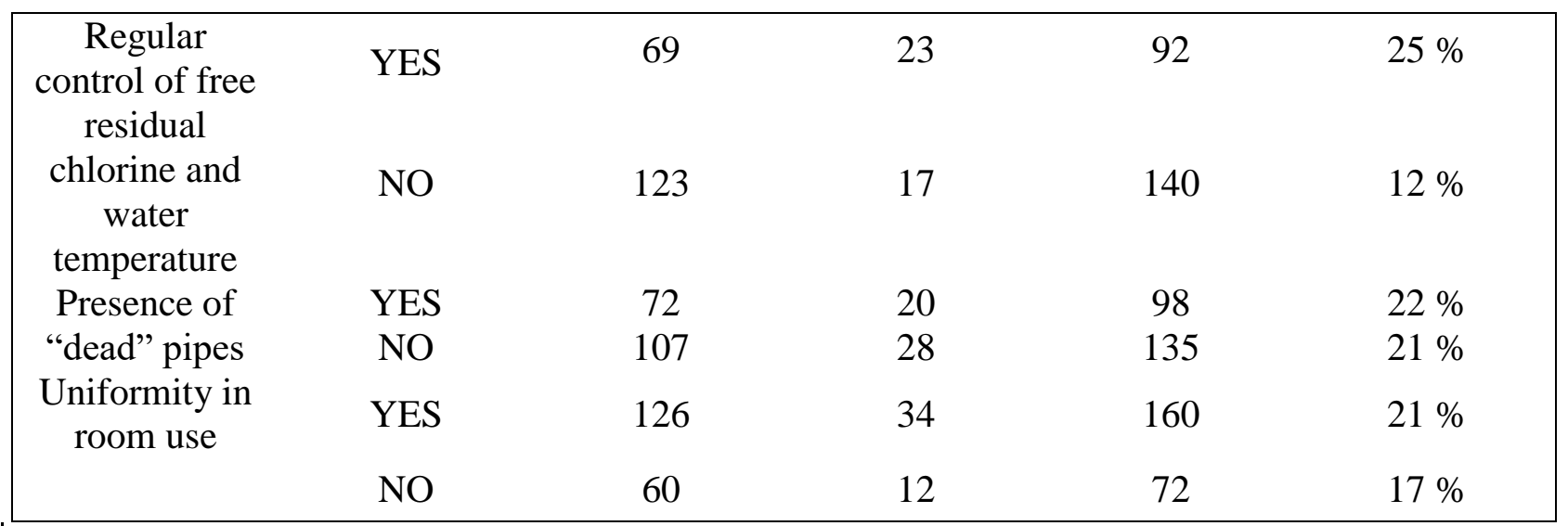

In the group of samples that disinfected the water in the system, 4 samples (10\%) were positive for the presence of the legionella, as shown in Table 6. In the group of 215 samples that did not disinfect the water system, the legionella was isolated in 59 samples (27\%). Table 6. shows that in the group of facilities that did not control free residual chlorine and water temperature, out of 140 samples, 17 were positive for the presence of legionella (17\%), and in the group of facilities that measured temperature and free residual chlorine, $23 \%$ of the was positive. From the same results it is evident that in the group of facilities that had "dead" tubes, out of 92 samples of water, $20(22 \%)$ were positive on the legionella. In the second group of facilities that did not have "dead" pipes, of the 135 samples 28 were positive on the legionella (21\%).

Figure 5. Shows the percentage representation of the answers to four significant questionnaires four risk factors. Only $15.68 \%$ of the facilities regularly disinfected the system for hot and cold water, the control of water temperature and concentration of free residual chlorine was performed in $39.60 \%$ of facilities, while $68.96 \%$ of the them covered by the test evenly used all the faucets in the building, and $41 \%$ of facilities in some way had stagnation of water in the water supply system. Out of the 160 facilities in which rooms were evenly used, legionella was isolated in 34 samples $(21 \%)$.

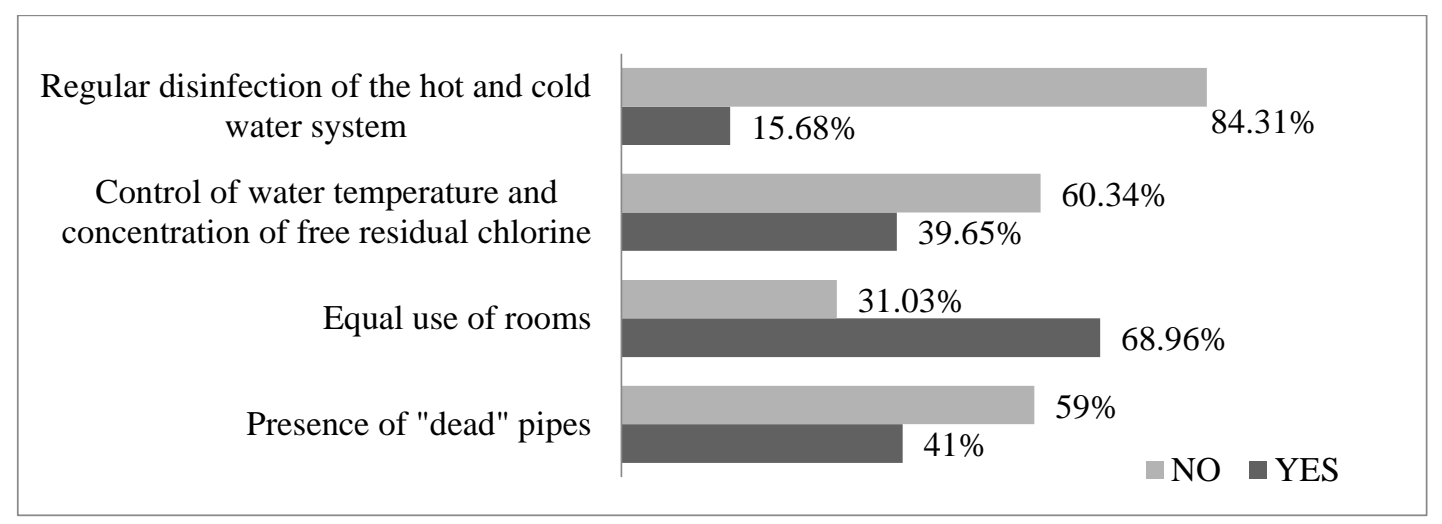

Figure 5: Current review of the basic parameters related to the appearance of legionella

Legionella are most often found in tanks and systems for cooling and heating of water in residential areas, industrial complexes, hospitals, hotels, other buildings for tourist accommodation, indoor and outdoor pools, recreational water complexes, cruises, open and 
closed fountains. In order to prevent the occurrence and suppress the spread of legionellosis, a risk assessment in these facilities is necessary, and on the basis of such assessment, the planning and implementation of corrective measures (28).

Water systems in hotels and other accommodation facilities for tourists are particularly susceptible to be colonised by legionella because they have large, complex water systems with large areas, and can be convenient to seasonal use with long periods of rare use or stagnation. In addition, staff is often employed temporarily, for shorter periods, what makes their training more difficult and affects the level of education (29).

The risk for the presence of legionella in the water was assessed based on hygienic conditions in the facilities. Out of 184 analysed samples of water in hotel facilities, 87 were rated with unsatisfactory hygiene conditions, and 14 were positive for the presence of Legionella spp. In 62 facilities with satisfactory hygienic conditions, Legionella spp. is isolated in 21 samples of drinking and bathing water, which is opposite to expectations and previous researches. These results are explained by the fact that many hotel facilities in the post-war period were partially restored. Partially means that the pipeline system of these facilities was not changed during the reconstruction process and this is a potential cause for legionella development even in hygienic satisfactory hotel facilities. The age of the building was taken as one of the key indicators in order to assess the risk of legionella occurrence in the water supply system within the facilities and due to the fact that some parts of the infrastructure in this country are quite old and date from the period after the Second World War. In Italy, according to research by Borella et al (4), the existence of old buildings is one of the reasons that explain the high frequency of legionelloses related travels. Also, materials previously used for the construction of water supply systems can stimulate the growth of bacteria of the genus Legionella and the production of biofilm. While assessing the age of the building, we were not always able to determine the actual data whether the reconstruction of the facility resulted in a complete replacement of the water related infrastructure. Studies by Vickers et al. (30) about the age of water storage tanks and their configuration show that older tanks were contaminated with L. pneumophill while newer ones, up to 5 years, were free from L.pneumophila colonies. This coincides with the results of this study, where among 34 facilities up to 10 years old, only 1 sample was positive for the legionella presence, and among 88 facilities in the category between 10 and 20 years, 29 were positive for the presence of legionella. It was expected that in the category of buildings over 20 years old the number of positive samples would increase, but in our examination out of 103 facilities, 10 of them were positive for the presence of the legionella, which explains that many facilities of that age were completely or partially reconstructed, including the reconstruction of water supply system.

The research has shown that copper taps i.e. copper ions slow down the development of L.pneumophila in water supply systems, but do not slow down the development of mycobacteria $(31,32,33)$. A positive correlation has been demonstrated between iron concentration and the presence of protozoa and L.pneumophila (34). Rakic et al. (35) found that out of the 127 water samples analysed, 10 contained a concentration of $\mathrm{Fe}$ above the maximum level. The corrosion (higher iron ion concentration) increases the surface roughness of the inner surface of the pipe, thereby increasing the surface area between the water and the water pipes, as well as the possible creation of ecological niches that are protected against disinfectants. The corrosion also increases 
the concentration of nutrients for biofilm growth that is firmly bound for rough surfaces. Uncontrolled biofilm growth can cause pipe blockage, especially in water system parts with low flow. The above factors stimulate the presence of legionella in the water distribution system.

\section{Conclusions and Recommendations}

The influence of the hygienic conditions of the facility on the presence of Legionella in water samples from taps, fountains, pools and water cooling and heating systems was examined. Out of 204 samples of drinking water from hotels, motels and hostel facilities, $14.78 \%$ of the category with unsatisfactory hygienic conditions were positive and from the category with satisfactory hygienic conditions, $23.59 \%$ were positive for the presence of Legionella spp., which is explained by the unchanged water supply system in older, restored facilities for people's accommodation. Out of 34 samples of water from the fountains, swimming pools and water from cooling and heating systems, $5.88 \%$ were positive for the presence of Legionella spp. In the category of buildings with unsatisfactory hygienic conditions, one sample of drinking water was positive for the presence of Legionella spp. In the category of facilities with unsatisfactory hygienic conditions, one sample of drinking water was positive for the presence of Legionella spp. X2 test shows that there is a statistically significant difference in the number of positive and negative samples between two categories of objects classified according to the estimated hygienic conditions in the drinking water of hotels, hostels and motels. Also, X2 test shows that there is a statistically significant difference in the number of positive and negative samples for the presence of Legionella spp. between two categories of facilities classified according to the estimated hygienic conditions in the waters of fountains, pools, and water cooling and heating systems. In this paper the presence of Legionella spp. is proven in touristic facilities over the territory of Bosnia and Herzegovina and there is a justified epidemiological risk for the appearance of legionellosis. It is necessary to implement preventive measures to address the development and colonization of legionella and to introduce active monitoring for presence of the agents responsible for causing legionella as well as to improve the control over the diseases associated with it.

\section{Acknowledgements}

This study was carried out in the laboratory for microbiological testing of food and water at the Public Health Institute FB\&H and in cooperation with the Sanitary Inspection of Canton Sarajevo.

\section{References}

[1] Zucceri, G., Asproulis, N. (2012): Detection of Pathogens in Water using Micro and NanoTechnology.

[2] Steinert, M., Hentschel, U,. Hacker, J. (2002): Legionella pneumophila: an aquatic microbe goes astray. FEMS Microbiol. Rev. 26:149-162.

[3] Fields, B., Benson, R., Besser, R. (2002): Legionella and Legionnaire's disease: 25 years of investigation. Clinical Microbiology Reviews, 15(3):506-526.

[4] Borella, P., Montagna, M.T., Stampi, S., Stancanelli, G., Spica, V.R., Triassi, M., Marchesi, I., Bargellini, A., Tato, D., Napoli, C., Zanett,i F., Leoni, E., Moro, M., Scaltriti, S., D'Alcala, G.R., 
Santarpia, R., Boccia, S. (2005): Legionella contamination in hot water of Italian hotels. Applied \& Environmental Microbiology 71(10): 5805-5813.

[5] Harb, O.S., Gao, L.Y., Abu Kwaik, Y. (2000): From protozoa to mammalian cells: a new paradigm in the life cycle of intracellular bacterial pathogens. Environ. Microbiol. 2:251-265.

[6] Rowbotham, T.J. (1980): Preliminary report on the pathogenicity of Legionella pneumophila for freshwater and soil amoebae. J. Clin. Pathol. 33:1179-1183.

[7] Kuiper, M.W., Wullings, B.A., Akkermans, A.D., Beumer, R.R., Van der Kooij, D. (2004): Intracellular proliferation of Legionella pneumophila in Hartmannella vermiformis in aquatic biofilms grown on plasticized polyvinyl chloride. Appl. Environ. Microbiol. 70:6826-6833.

[8] Momba, M.N.B., Kfir, R., Venter, S.N., Cloete, T.E. (2000): An overview of biofilm formation in distribution systems and its impact on the deterioration of water quality. Water SA (Pretoria) 26:59-66.

[9] Murga, R., Forster, T.S., Brown, E., Pruckler, J.M., Fields, B.S., Donlan, R.M. (2001): The role of biofilms in the survival of Legionella pneumophila in a model potable water system. Microbiology 147:3121-3126.

[10] Edelstein, P.H., Cianciottp, N.P., Mandell, G.L., Bennett, J.E., Dolin, R. (2005): Principles and practice of infectious diseases. 6. izd. Philadelphia: Elsevier, Churchill Livingstone; 2711.

[11] Kuzman, I., Puljiz, I., (2005): Legionarska bolest: praktični pristup dijagnostici i liječenju, Medicus Vol. 14, No. 1, 107 - 113.

[12] Gomez-Valero, L., Rusniok, C., Buchrieser, C. Legionella pneumophila: Population genetics, phylogeny and genomics. Infect Genet Evol. 2009; 9: 727-739.

[13] Schoen, M.E., Ashbol., N.J. (2011): An in-premise model for Legionella exposure during showering events. Water Res. 2011; 45: 5826-5836.

[14] Berry, D-, Xi, C., Raskin, L. (2006): Microbial ecology of drinking water distribution systems. Curr. Opin. Biotechnol. 17, 297-302. Blackburn, B. G., Craun, G. F., Yoder, J. S., Hill, V., Calderon.

[15] Borella, P., Montagna, M.T., Spica, V.R, Stampi, S., Stancanelli, G., Triassi, M., Negelia, R., Marchesi, I., Guglielmina, F., Tato, D., Napoli, C., Quaranta, G., Laurenti, P., Leoni, E., De Luca, G., Ossi, C., Moro, M.D., Alcala, G.R. (2004): Legionella infection risk from domestic hot water. Emerging Infectious Diseases 10(3): 457-464.

[16] Eboigbodin, K.E., Seth, A., Biggs, C.A. (2008): A review of biofilms in domestic plumbing. J. Am Water Works Assoc.; 100: 131-138.

[17] Atlas, R. M. 1999. Legionella: from environmental habitats to disease, pathology, detection and control. Environ. Microbiol. 4:283-293.

[18] Moritz, M.M., Flemming, H.C., Wingender, J. (2010): Integration of Pseudomonas aeruginosa and Legionella pneumophila in drinking water biofilms grown on domestic plumbing materials. Int J Hyg Envir Heal.; 213: 190-197.

[19] Bagh, L.K., Albrechtsen, H.J., Arvin, E., Ovesen, K. (2004): Distribution of bacteria in a domestic hot water system in a Danish apartment building. Water Res.; 38: 225-235.

[20] Wingender, J., Flemming, H.C. (2004): Contamination potential of drinking water distribution network biofilms. Water Sci Technol. 2004; 49: 277-286.

[21] Bertram, J., Chartier, Y., Lee, J.V., Pond, K., Whipple, S.L. (2007): Legionella and the prevention of legionellosis. Geneva, Switzerland, WHO Press., World Health Organization, p. 3037.

[22] Lau, H., Ashbolt, N. (2009): The role of biofilms and protozoa in Legionella pathogenesis: implications for drinking water. J Appl Microbiol.; 107:368-378.

[23] Donlan, R.M., Forster, T., Murga, R., Brown, E., Lucas, C., Carpenter, J., Fields, B. (2005): Legionella pneumophila associated with the protozoan Hartmanella vermiformis in a model multi-species biofilm has reduced susceptibility to disinfectants. Biofouling, 21, 1-7.

[24] Barbot, V., Robert, A., Rodier, M.H., Imbert, C. (2012): Update on infectious risks associated with dental unit waterlines. FEMS Immunol. Med. Microbiol., 65, 196-204. 
[25] Coleman, D.C., O’Donnell, M.J., Shore, A.C., Russell, R.J. (2009): Biofilm problems in dental unit water systems and its practical control. J. Appl. Microbiol., 106, 1424-143.

[26] Walker, J.T., Marsh, P.D. (2007): Microbial biofilm formation in DUWS and their control using disinfectants, Journal of dentristry, Volume 35, Issue 9, Pages 721 - 730

[27] EWGLI (2002): European guidelines for control and prevention of travel associated Legionnaires' disease. Part 2. Definitions and procedures for reporting and responding to cases of travel associated Legionnaires' disease, p. 15-20. PHLS, London, United Kingdom.

[28] Obradović, Z., Balta, S., Mešić, S., Pašagić, S. (2014): Legionellosis - risk assessment, Zbornik Radova: 26. Znanstveno - Stručno - Edukativni Seminar DDD i ZUPP 2014._Djelatnost dezinfekcije, dezinsekcije, deratizacije i zaštite uskladištenih poljoprivrednih proizvoda, Split, 25. do 28. ožujka 2014. pp. 189-197.

[29] Yu, V. L. 2002. Legionella surveillance: political and social implications-a little knowledge is a dangerous thing. J. Infect. Dis. 185:259-261

[30] Vickers, R.M., Yu, V.L., Hanna, S.S., Muraca, P., Diven, W., Carmen, N., Taylor, F.B. (1987): Determination of L.pneumophila contamination of water distribution systems: 15 hodpital prospectove study. Infect Control 8:957-363.

[31] Kusnetsov, J., Iivanainen, E., Elomaa, N., Zacheus, O., Martikainen, P. J. (2001): Copper and silver ions more effective against legionellae than against mycobacteria in a hospital warm water system. Appl Environ Microbiol. 2001; 35: 4217-4225.

[32] Van der Kooij, D., Veenendaal, H.R., Scheffer, W.J. (2005): Biofilm formation and multiplication of Legionella in a model warm water system with pipes of copper, stainless steel and crosslinked polyethylene. Water Res. 2005; 39: 2789-2798.

[33] Bargellini, A., Marches, I., Righi, E., Ferrari, A., Cencetti, S., Borella, P., Rovesti, S. (2011): Parameters predictive of Legionella contamination in hot water systems: association with trace elements and heterotrophic plate counts. Water Res. 2011; 45: 2315-2321.

[34] Cianciotto, N.P. (2007): Iron acquisition by Legionella pneumophila. Biometals. 2007; 20: 32333.

[35] Rakić, A., Perić, J., Foglar, L. (2012): Influence of temperature, chlorine residual and heavy metals on the presence of Legionella pneumophila in hot water distribution system. Annals of Agricultural and Environmental Medicine 2012, Vol 19, No 3, 431-436.

*Corresponding author.

E-mail address: a.besic@ zzjzfbih.ba 